\title{
Germination Performance of Yellow Cosmos: Understanding Its Invasion under Tropical Conditions
}

\author{
Marcelo Claro de Souza ${ }^{1}$, Carita Liberato do Amaral ${ }^{2}$, Henrique Hespanhol Tozzi ${ }^{1}$ \\ $\&$ Pedro Luis da Costa Aguiar Alves ${ }^{3}$ \\ 1 Programa de Pós-Graduação em Ciências Biológicas (Biologia Vegetal) - Departamento de Botânica, \\ Universidade Estadual Paulista (UNESP), Rio Claro-SP, Brazil \\ ${ }^{2}$ Programa de Pós-Graduação em Agronomia (Produção Vegetal), Departamento de Biologia Aplicada à \\ Agropecuária, Universidade Estadual Paulista (UNESP), FCAV, Jaboticabal-SP, Brazil \\ ${ }^{3}$ Universidade Estadual Paulista (UNESP), Departamento de Biologia Aplicada à Agropecuária, FCAV, \\ Jaboticabal-SP, Brazil \\ Correspondence: Marcelo Claro de Souza, Programa de Pós-Graduação em Ciências Biológicas (Biologia Vegetal) \\ - Departamento de Botânica, Universidade Estadual Paulista (UNESP), Rio Claro-SP, Brazil. E-mail: \\ marcelo.claro.souza@gmail.com
}

Received: December 22, 2012 Accepted: February 1, 2013 Online Published: March 15, 2013

doi:10.5539/jas.v5n4p56

URL: http://dx.doi.org/10.5539/jas.v5n4p56

\begin{abstract}
To further investigate the recently observed invasion of a new weed in the São Paulo areas, Brazil, we studied the germination performance and emergence characteristics of Bidens sulphurea. We measured the seed germination under different fixed temperatures $\left(15,20,25,30\right.$ and $\left.35^{\circ} \mathrm{C}\right)$, photoperiods $(18 \mathrm{~h} / 6 \mathrm{~h}, 12 \mathrm{~h} / 12 \mathrm{~h}, 6 \mathrm{~h} / 18 \mathrm{~h}$ and $0 \mathrm{~h} / 24 \mathrm{~h}$ [light/dark], respectively), light quality (white, blue, yellow, green, red and dark condition); and emergence in two seasons (winter and spring) in different sowing depths $(0,1,3,5,7$ and $9 \mathrm{~cm})$. This species has the ability to germinate and emerge above $90 \%$ in a range of conditions of light, but it is very sensitive to variations in temperature, and several reductions on its germination and emergence are found bellow $20^{\circ} \mathrm{C}$. The emergence of this species is severely controlled by seasonality and could occur up to $9 \mathrm{~cm}$ depth in Brazilian spring.
\end{abstract}

Keywords: Bidens sulphurea, emergence, temperature, light quality, sowing depth

\section{Introduction}

Bidens sulphurea (yellow cosmos) is an annual weed with sexual reproduction, originated in Central America and disseminated for ornamental purposes (Kissmann \& Groth, 1999). Its population is building-up rapidly and spreading around agricultural and urban sites on São Paulo state, Brazil. As well as Bidens pilosa (Kissmann \& Groth, 1999), this species has the potential to be one of the main weeds in tropical zones. Indeed neither biological nor ecological information are available on the environmental factors influencing seed germination and seedlings emergency for this species.

The environmental conditions such as light, temperature, and the association of both (J. M. Baskin \& C. C. Baskin, 2004) and the vertical distribution of the seeds on the soil (Souza, Pitelli, Simi, \& Oliveira, 2009) are the main factors that influence seed germination and emergence in the tropics, promoting or breaking the dormancy of the seeds. Seed banks are the main source of weeds regeneration and potential for spreading in agricultural sites (Carmona, 1992).

Seeds, in general, germinate within a broad temperature range; the optimum temperature allows the highest seed germination performance (Roberto \& Habermann, 2010). In addition, the maximum and minimum temperatures, above and below which seed germination may not occur, help to characterize the geographical and climatic region where seeds or fruits were harvested.

The knowledge of optimum conditions for seed germination, mainly temperature and light, are fundamental, since germination success is directly linked to each species' ecological characteristics (Figliolia, Oliveira, \& Pinã-Rodrigues, 1993; Sousa, L. F. Braga, F. B. Braga, Sá, \& Moraes, 2000) as well as speed (Carvalho \& Nakagawa, 2000). The soil depth from which a seed can germinate and produce seedlings is variable between 
species (Guimarães, Souza, \& Pinho, 2002), as Euphorbia heterophylla (Machado Neto \& Pitelli, 1988), Desmodium purpureum (Oliveira Jr. \& Delistoianov, 1996), Ipomoea asarifolia (Dias Filho, 1996) and Amaranthus retroflexus (Ghorbani, Seel, \& Leifert, 1999). These data are very important to adopt a more appropriate management practice, such as herbicides on pre or post emergence or mechanical control (harrows and cultivators).

Weeds use efficiently the natural resources in nature, especially sunlight (Schmitt \& Wulff, 1993). Consequently, they are also very well adapted to specific environments, showing highly heritable traits such as the high seed production (Ackerly et al., 2000; Masin, Zuin, Archer, Forcella, \& Zanin, 2005), aggressiveness and success in spreading.

To further investigate the invasion "aggressiveness" of $B$. sulphurea, we measured the influence of temperature, photoperiod, quality of incident light and seeds sowing period at different depths, on seed germination and seedling emergence of this species. The main question addressed was testing the assumption that high spreading of $B$. sulphurea occurs because the species show high germination and the environmental changes related to light and temperature exercise small influence in this process.

\section{Material and Methods}

\subsection{Plant Material}

Bidens sulphurea achenes (seeds) were randomly collected from mature capitula of healthy adult plants, in a few hours before beginning each experiments at the agricultural fiels on Faculdade de Ciências Agrárias e Veterinárias (FCAV-UNESP), Jaboticabal city, São Paulo state, Brazil. We adopted this procedure to avoid seed dormancy caused by storage (Finch-Savagel \& Leubner-Metzger, 2006).

\subsection{Effects of Temperature and Light on Germination}

The three experiments were conducted independently in a germination chamber using a completely randomized design, being determined the effects of: 1 - temperature $\left(15,20,25,30\right.$ and $35^{\circ} \mathrm{C}$, under $12 / 12$ photoperiod); 2- photoperiod (18/6, 12/12, 6/18 and $0 / 24$ hours light/dark at $\left.25^{\circ} \mathrm{C}\right) ; 3$ - quality of incident light (yellow, blue, white, green, red and complete dark at $25^{\circ} \mathrm{C}$ ), on germination of $B$. sulphurea. In all experiments 20 seeds were used in each box per repetition ( 4 repetitions), distributed in five columns in each box. For moisture maintenance and standardization, two filter paper sheets moistened with $10 \mathrm{~mL}$ of distilled water were used per treatment. Seed was considered germinated when the radicle visibly protruded through the seed coat (Reddy \& Singh, 1992).

To test germination in the dark, boxes were wrapped in a double layer of aluminum foil. The light quality was obtained wrapping the box in a cellophane foil (yellow, blue, white, green and red) (Almeida \& Mundstock, 2001). Germination was recorded daily during seven days, by removing germinated seeds. At the end of this period germination $(\mathrm{G} \%$ ) and germination rate (GR) were calculated (Maguire, 1962). All the evaluations were done in a dark room under green light (Felippe, Válio, Pereira, Sharif, \& Vieira, 1983).

\subsection{Influence of Seasonality on Seed Burial Depth}

These experiments were conducted using two sowing seasons, the first one conducted on June 2009 (winter) and the second one on September 2009 (spring).

Fifty seeds were sowed in pots of $5 \mathrm{~L}$ at depths of 0 (soil surface), 1, 3, 5, 7 and $9 \mathrm{~cm}$, in a randomized design with five repetitions. The soil (38\% clay, $5 \%$ silt and $57 \%$ sand) was dried in the shadow and passed through a $5-\mathrm{mm}$ sieve. Soil in the pots was moistened initially using a mist sprayer and then sub irrigated to maintain adequate soil moisture. Daily, for 21 days after sowing (DAS), seedlings were counted and removed (Souza et al., 2009). With the daily emergence data, for each sowing season, emergence rate was calculated (ER) (Maguire, 1962). Seedling emergence was defined as the coleoptile being visible at the soil surface (Reddy \& Singh, 1992).

\subsection{Statistical Analysis}

The data were statistically analyzed using one-way ANOVA, and the means were compared by Tukey test at $5 \%$ level. For germination $(\mathrm{G} \%)$ and emergence $(\mathrm{E} \%)$ percentage, $\arcsin (\operatorname{sqr}(\mathrm{x}+0.5) / 100)$ was calculated to perform the statistical analysis. 


\section{Results and Discussion}

\subsection{Effects of Temperature and Light on Germination}

The highest germination percentage $(\mathrm{G} \%)$ was observed between 25 and $30^{\circ} \mathrm{C}(94$ and $73 \%$ respectively) and the lowest between 15 and $20^{\circ} \mathrm{C}(1.25 \%$ for both treatments). Similar effects were observed in germination rate (GR), where the highest rate (11.79) was observed at $25^{\circ} \mathrm{C}$ and the lowest between 15 and $20^{\circ} \mathrm{C}(0.08$ and 0.04 respectively) (Figure 1). Seeds placed at 25 and $30^{\circ} \mathrm{C}$ treatments spent three days to achieve $50 \%$ germination; at $35^{\circ} \mathrm{C}$ spent seven days and at 15 and $20^{\circ} \mathrm{C}$ did not reach two percent (Figure 1), suggesting that the optimum temperature for this species occurs near $25^{\circ} \mathrm{C}$.
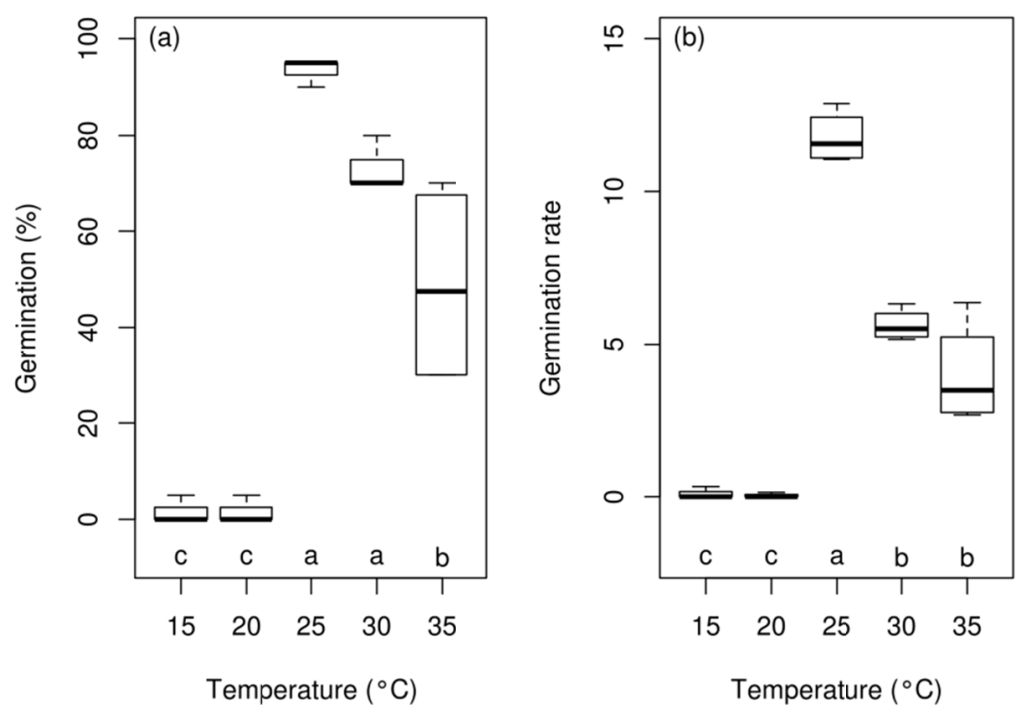

Figure 1. Boxplot of germination (G\%) and germination rate (GR) of Bidens sulphurea seeds submitted to

different temperatures. The line in the middle of each box indicates the $50^{\text {th }}$ percentile of the observed distribution; the bottom and top parts of each box represent the $25^{\text {th }}$ and $75^{\text {th }}$ percentiles, respectively; the bottom and top error bars of each box are the $5^{\text {th }}$ and the $95^{\text {th }}$ percentiles of the observed distribution. Different letters indicate significant difference $(P<0.05)$ between the treatments

Optimum temperature is classified as promoting the highest germination rate in the shortest period of time (Malavasi, 1988). Therefore, high temperatures may result in decreased amino acid supply, compromising protein synthesis, and can also denaturate proteins, compromise anabolic reactions, and alter cellular membrane fluidity, causing cellular material loss (Riley, 1981). On the other hand, lower temperatures decrease metabolic rates to the point where vital reactions can no longer operate, and can also influence the cellular membrane physical state, from the liquid-crystalline to crystalline state (Hendricks \& Taylorson, 1976).

Non plastic weeds require a critical temperature to germinate, while plastic species germinate over a range of temperatures (Burke, Thomas, Spears, \& Wilcut, 2003). In this case B. sulphurea presented moderate plasticity, germinating above $50 \%$ between 25 and $35^{\circ} \mathrm{C}$. The same plasticity can be observed in a congeneric species, $B$. pilosa, in which maximum germination occurs between 25 and $30^{\circ} \mathrm{C}$, and inhibition occurs below $20^{\circ} \mathrm{C}$ and above $35^{\circ} \mathrm{C}$ (Reddy \& Singh, 1992). Considering that in tropical fields the soil average temperature is around $25^{\circ} \mathrm{C}$, temperature would not be a limiting factor for germination throughout the year. Not only congeneric species present this behavior, the highest germination of Rottboellia cochinchinensis occurs at $25^{\circ} \mathrm{C}$ and a severe reduction could be observed bellow $10^{\circ} \mathrm{C}$ and above $30^{\circ} \mathrm{C}$ (Silva, Parreira, Alves, \& Pavani, 2009).

In general, when exposed to light (treatments $18 / 6,12 / 12$ and 6/18), germination was higher than $90 \%$, while at the dark it was around $70 \%$. In addition, germination rate decreases drastically when we compare light (10.0 14.54) and dark (4.66) treatments (Figure 2). The time to $50 \%$ germination $\left(\mathrm{T}_{50}\right)$ was 1 day for the $18 / 6$ treatment, 2 days for $12 / 12$ and $6 / 18$, and 4 days to $0 / 24$ treatment. 

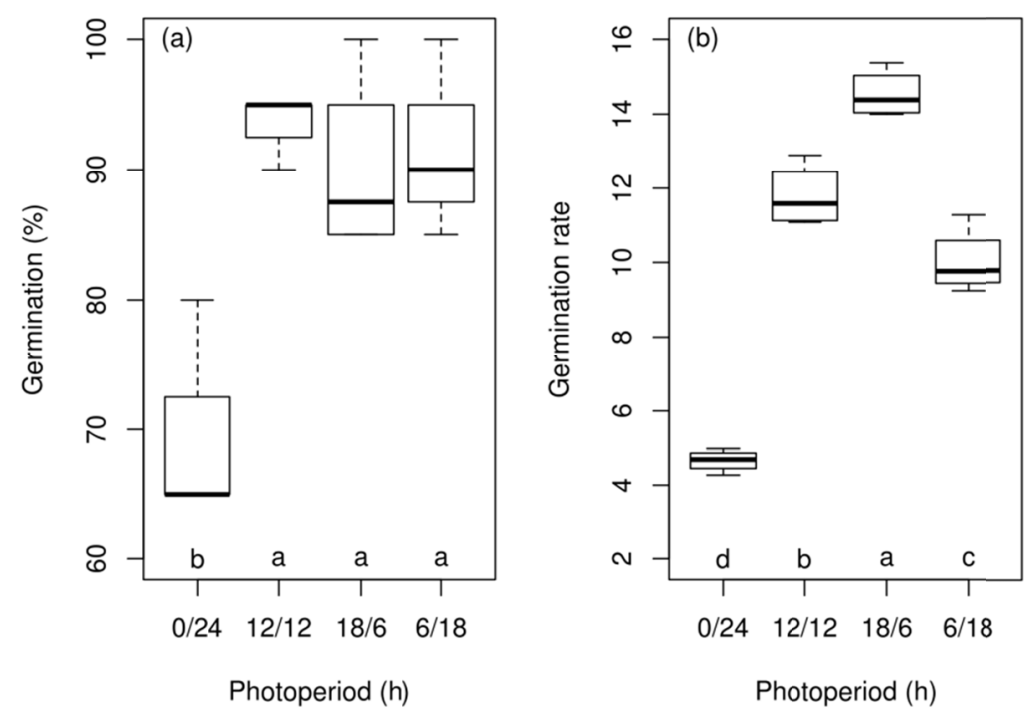

Figure 2. Boxplot of germination (G\%) and germination rate (GR) of Bidens sulphurea on different photoperiods. Box plot characteristics are as described in Figure 1

For most of aggressive weeds, light is not a requirement for germination. Several weeds such as Rumex obtusiflius (Benvenuti, Macchia, \& Miele, 2001) and Alternanthera tenella (Canossa et al., 2008) germinate above $70 \%$ in absence of light, suggesting that these species could germinate well on the surface and in depth sowing, facilitating its spread.

In an agricultural environment, the seeds can be exposed to light for prolonged periods, and light, in most cases, presents a complex spectral composition (Ishimine, Murayama, \& Matsumoto, 1988). Light qualities did not affect the germination percentage $(93.3-97.5 \%)$ and neither the germination rate $(7.60-9.36)$. We observed reductions in absence of light in G\% (68.80\%) and GR (4.62) (Figure 3), and the $\mathrm{T}_{50}$ was similar in all treatments, being around 2 days in presence of light (R, G, Y, B and $\mathrm{W}$ ) and 3 days in absence of light (D).

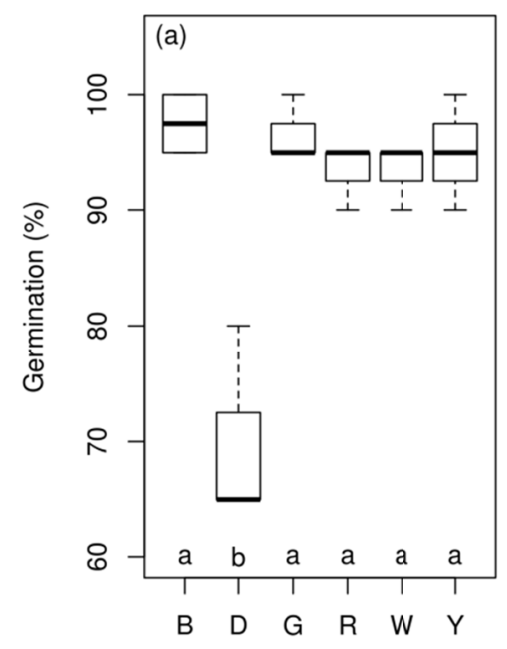

Light quality

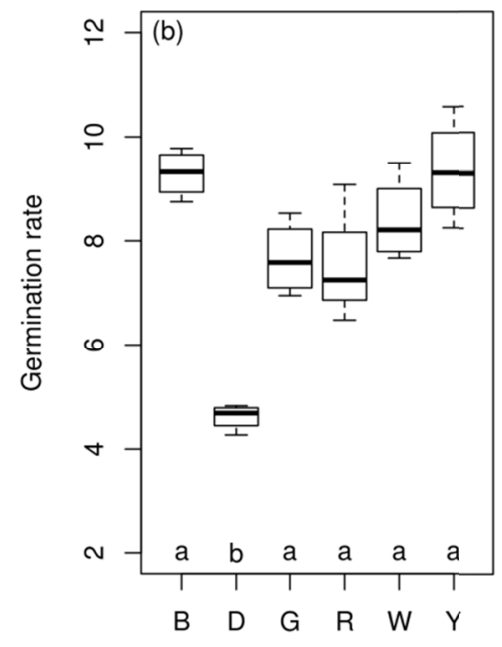

Light quality

Figure 3. Boxplot of germination (G\%) and germination rate (GR) of Bidens sulphurea in different light qualities (B-blue, D-dark, G-green, R-red, W-white, Y-yellow). Box plot characteristics are as described in Figure 1 
While the seeds of some species need critical light and temperature conditions to germinate, others can germinate equally in both light and dark (Chauhan \& Jonson, 2010) and a range of temperatures (Burke et al., 2003). The ability of $B$. sulphurea to germinate over a range of light and temperature conditions may explain its ability to emerge year round in tropical climates and its adaptations to spread from São Paulo state.

\subsection{Influence of Seasonality on Seed Burial Depth}

The seasonality and sowing depths had a marked influence on the emergence of B. sulphurea seedlings as well as observed for B. pilosa (Souza et al., 2009). In June the emergence of this species began around 7 days after sowing (DAS) and in September around 4 DAS. The highest average emergence (E\%) observed in June was 22\% (Figure 4A) while in September was 84\% (Figure 4C).

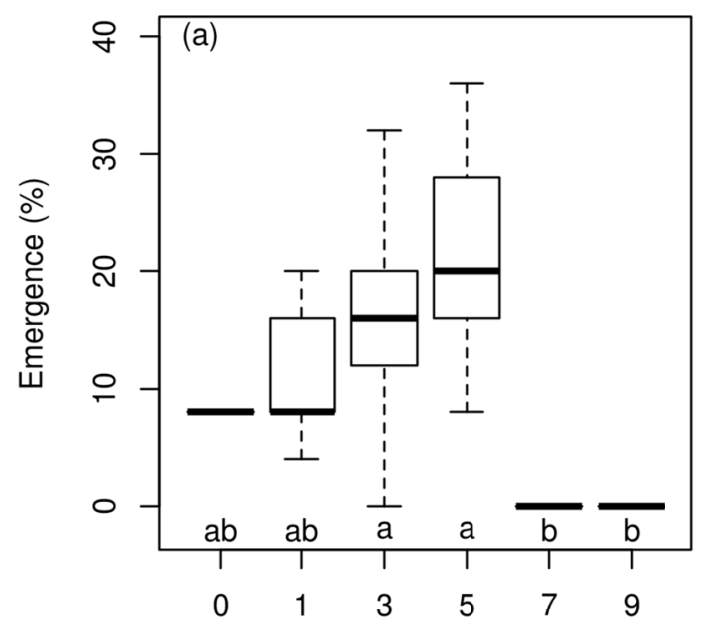

Sowing depth (cm) - June

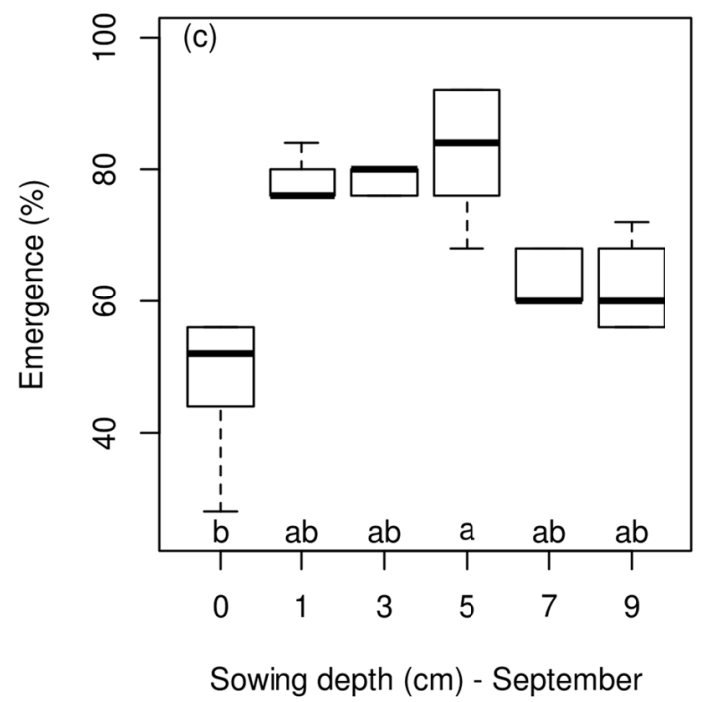

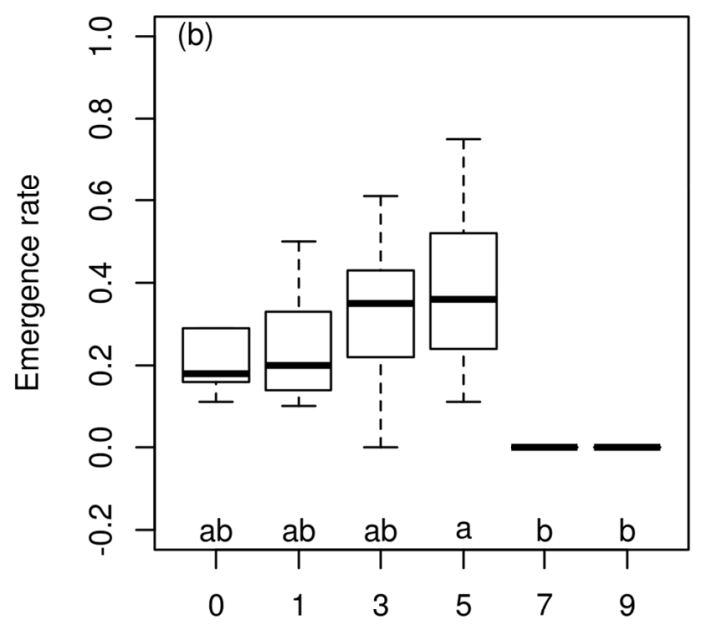

Sowing depth (cm) - June

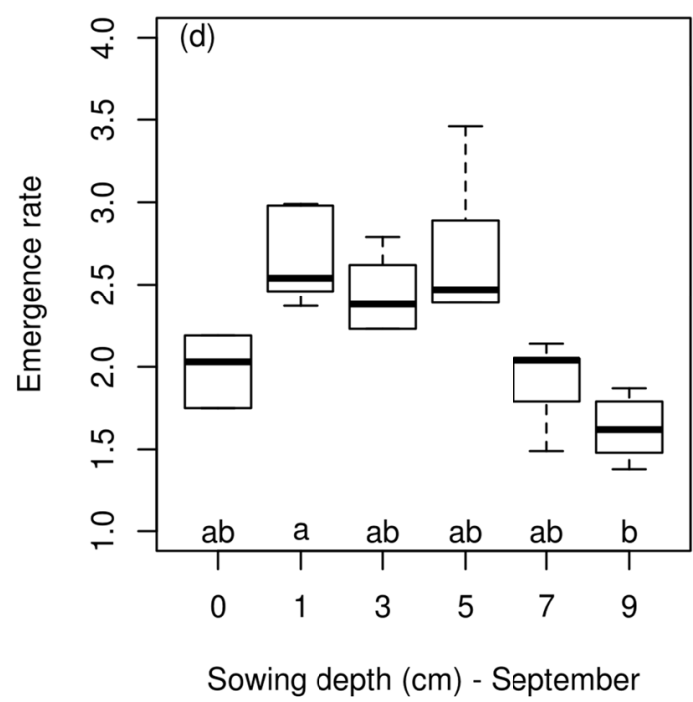

Figure 4. Boxplot of emergence (E\%) and emergence rate (ER) of Bidens sulphurea seeds deposited on different sowing depths in two seasons (June [E\% (A), ER (B)] and September [E\% (C), ER (D)] 2009). Box plot characteristics are as described in Figure 1

This anticipation and the increment at the seedlings emergence are probably due to a temperature increase recorded in September compared to June, being that in June 2009 the minimum registered temperature was $8.6^{\circ} \mathrm{C}$ and maximum $27.7^{\circ} \mathrm{C}$ (monthly average $17.8^{\circ} \mathrm{C}$ ) and in September 2009 varied between $12.9^{\circ} \mathrm{C}$ and $33.5^{\circ} \mathrm{C}$ 
(monthly average $22.5^{\circ} \mathrm{C}$ ). These results are consistent with the stimulation of germination by temperature (Figure 1).

Seedling emergence of $B$. sulphurea was greatly influenced by seed burial depth mainly in June when the emergence bellow $7 \mathrm{~cm}$ depth was less than $1 \%$ and the ER was near zero (Figure 4B). The highest emergence was observed between 3 and $5 \mathrm{~cm}$ depth (18 and 22\%) and the ER was 0.32 and 0.40. In September, as a result of temperature increase, the E\% was above 50\% (Figure 4C) even in the all depths and the ER increased in all depths too. In general the highest emergence in June was $24 \%$ and in September $84 \%$.

In our study of temperature and light (Figures 1 and 2) germination percentage was higher than observed at the soil surface in September. This difference could be due to poor soil-seed contact or limited water availability on the soil surface than on the filter papers (Ghorbani et al., 1999). Seeds buried below $2 \mathrm{~mm}$ on the soil surface usually receive less than $1 \%$ of incident light (Egley, 1986). According to our study of light (Figures 2 and 3) B. sulpurea seeds germinated above $60 \%$ in dark conditions. In this case the observed variations on emergence at different sowing depths in both seasons are exclusively related to variations on soil temperature, suggesting that this species is light insensible but very sensible to temperature.

\section{Conclusions}

The results of this study highlight the $B$. sulphurea ability to germinate and emerge above $90 \%$ in a broad range of conditions of light, confirming our hypothesis, but this species is very sensitive to variations in temperature, and a severe reduction on germination and emergence is found bellow $20^{\circ} \mathrm{C}$. The emergence of this species is severely controlled by seasonality and could germinate up to $9 \mathrm{~cm}$ depth in Brazilian spring.

\section{References}

Ackerly, D. D., Dudley, S. A., Sultan, S. E., Schmitt, J., Coleman, J. S., Linder, R., ... Lechowicz, M. J. (2000). The evolution of plant ecophysiological traits: recent advances and future directions. Bioscience, 50(11), 979-995. http://dx.doi.org/10.1641/0006-3568(2000)050[0979:TEOPET]2.0.CO;2

Baskin, J. M., \& Baskin, C. C. (2004). A classification system for seed dormancy. Seed Science Research, 14(1), 1-16. http://dx.doi.org/10.1079/SSR2003150

Benvenuti, S., Macchia, M., \& Miele, S. (2001). Light, temperature and burial depth effects on Rumex obtusifolius seed germination and emergence. Weed Research, 41(2), 177-186. 10.1046/j.1365-3180.2001.00230.x

Burke, I. C., Thomas, W. E., Spears, J. F., \& Wilcut, J. W. (2003). Influence of environmental factors on after-ripened crowfootgrass (Dactyloctenium aegyptium) seed germination. Weed Science, 51(3), 342-347. http://dx.doi.org/10.1614/0043-1745(2003)051[0342:IOEFOA]2.0.CO;2

Canossa, R. S., Oliveira Jr., R. S., Constantin, J., Braccini, A. L., Biffe, D. F., Alonso, D. G., ... Blainski, E. (2008). Effect of temperature and light on joyweed (Alternanthera tenella) seed germination. Planta Daninha, 26(4), 745-750. http://dx.doi.org/10.1590/S0100-83582008000400005

Carmona, R. (1992). Problematic and management of weed seed Banks in agricultural soils. Planta Daninha, 10(1-2), 5-16. http://dx.doi.org/10.1590/S0100-83581992000100007

Carvalho, N. M., \& Nakagawa, J. (2000). Diásporos: ciência, tecnologia e produção (4th ed.). FUNEP, Jaboticabal.

Chauhan, B. S., \& Johnson, D. E. (2010). The role of seed ecology in improving weed management strategies in the tropics. Advances in Agronomy, 105, 221-262. http://dx.doi.org/10.1016/S0065-2113(10)05006-6

Dias Filho, M. B. (1996). Germination and emergence of Stachytarpheta cayennensis and Ipomoea asarifolia. Planta Daninha, 14(2), 118-126. http://dx.doi.org/10.1590/S0100-83581996000200005

Egley, G. H. (1986). Stimulation of weed seed germination in soil. Reviews of weed science, 2, 67-89.

Felippe, G. M., Válio, I. F. M., Pereira, M. F. A., Sharif, R. R., \& Vieira, S. R. (1983). Fisiologia do desenvolvimento vegetal. Campus, Rio de Janeiro.

Figliolia, M. B., Oliveira, E. C., \& Pinã-Rodrigues, F. C. M. (1993). Análise de sementes. In I. B. Aguiar, F. C. M. Pinã-Rodrigues, \& M. B. Figliolia (Eds.), Sementes florestais tropicais (pp. 137-174). ABRATES, Brasília.

Finch-Savagel, W. E., \& Leubner-Metzger, G. (2006). Seed dormancy and the control of germination. New Phytologist, 171(3), 501-523. http://dx.doi.org/10.1111/j.1469-8137.2006.01787.x 
Ghorbani, R., Seel, W., \& Leifert, C. (1999). Effects of environmental factors on germination and emergence of Amaranthus retroflexus. Weed science, 47(5), 505-510.

Guimarães, S. C., Souza, I. F., \& Pinho, E. V. R. V. (2002). Tridax procumbens emergence as a function of sowing depth, substrate clay content and light incidence. Planta Daninha, 20(4), 413-419. http://dx.doi.org/10.1590/S0100-83582002000300012

Hendricks, S. B., \& Taylorson, N. B. (1976). Variation in germination and amino acid leakage of seeds with temperature related to membrane phase change. Plant Physiology, 58(1), 7-11. http://dx.doi.org/10.1104/pp.58.1.7

Ishimine, Y., Murayama, S., \& Matsumoto, S. (1988). Physiological and ecological characteristics of sugarcane field weeds in the Ryukyu Island. Effect of shade on growth and seed production of (Rottboellia exaltata and Solanum alatum). Weed Research, 33(2), 114-121.

Kismann, K. G., \& Groth, D. (1999). Plantas infestantes e nocivas (2nd ed.). Tomo II. BASF, São Paulo.

Machado Neto, J. G., \& Pitelli, R. A. (1988). The sowing depth on the emergency of wild peanut. Pesquisa Agropecuária Brasileira, 23(11), 1203-1208.

Maguire, J. D. (1962). Speed of germination aid selection and evaluation for seedling emergence and vigor. Crop Sciecne, 2(2), 176-177.

Malavasi, M. M. (1988). Germinação de sementes. In F. C. M Piña-Rodrigues (Ed.), Manual de análise de sementes florestais (pp. 25-40). Fundação Cargill, Campinas.

Masin, R., Zuin, M. C., Archer, D. W., Forcella, F., \& Zanin, G. (2005). Weed turf: A predictive model to aid control of annual weeds in turf. Weed Science, 53(2), 193- 201. http://dx.doi.org/10.1614/WS-04-066R1

Oliveira, Jr., R. S., \& Delistoianov, F. (1996). Sowing depth and dormancy breaking methods affecting Desmodium purpureum (Mill) Fawc. et Rend (Leguminosae - Papilionoideae) germination and emergence. Revista Brasileira de Botânica, 19, 221-225.

Reddy, K. N., \& Singh, M. (1992). Germination and emergence of hairy beggarticks (Bidens pilosa). Weed Science, 40(2), 195-199.

Riley, G. J. P. (1981). Effects of high temperature on protein synthesis during germination of maize. Planta, 151(1), 75-80.

Roberto, G. G., \& Habermann, G. (2010). Morphological and physiological responses of the recalcitrant Euterpe edulis seeds to light, temperature and gibberellins. Seed Science and technology, 38(2), 367-378.

Schmitt, J., \& Wulff, R. D. (1993). Light spectral quality, phytochrome and plant competition. Trends in Ecology and Evolution, 8(2), 47-51. http://dx.doi.org/10.1016/0169-5347(93)90157-K

Silva, C. E. B., Parreira, M. C., Alves, P. L. C. A., \& Pavani, M. C. M. D. (2009). Germination aspects of itchgrass (Rottboellia cochinchinensis). Planta Daninha, 27(2), 273-281. http://dx.doi.org/10.1590/S0100-83582009000200009

Sousa, M. P., Braga, L. F., Braga, F. B., Sá, M. E., \& Moraes, M. L. T. (2000). Influência da temperatura na germinação de sementes de sumaúma (Ceiba pentandra (Linn.) Gaertn.) - bombacaceae. Revista Brasileira de Sementes, 22(1), 110-119.

Souza, M. C., Pitelli, R. A., Simi, L. D., \& Oliveira, M. C. J. (2009). Seed emergence of Bidens pilosa at $\begin{array}{lllll}\text { different } \quad \text { sowing } \quad \text { depths. } & \text { 29-34. }\end{array}$ http://dx.doi.org/10.1590/S0100-83582009000100005 